\title{
Marketing Research of the Academic Library of the Siberian Federal University
}

\author{
O.I. Babina*, R.A. Baryshev \\ Siberian Federal University, 79 Svobodny Av., Krasnoyarsk, 660041 Russia \\ Corresponding Author: babina62@yahoo.com
}

Copyright (C) 2014 Horizon Research Publishing All rights reserved.

\begin{abstract}
A new and a very urgent phenomenon in the activity of university libraries is carrying out a marketing research. It enables the administration to study the interests, needs and requirements of the readers, analyse the most demanded information and library services and resources, and guide the libraries to provide the users with the resources and services according to their needs. The article presents the analysis results of the marketing research carried out at the Academic Library of the Siberian Federal University in Krasnoyarsk city. The marketing research consists of several blocks: the comfort of the working environment for the users, the demand for the information resources and services, quality of the library service provided to the readers.
\end{abstract}

Keywords Marketing Research of the Libraries, Library Service, Information Resources and Services, Quality of Reader Service

\section{Introduction}

The Academic Library of the Siberian Federal University (SibFU AL) is a large information and cultural centre that provides information and bibliographical services and resources to a wide section of the population of Krasnoyarsk Krai and the Eastern Siberia. For this reason is becomes important to select the direction for the research dedicated to the analysis of demand for the present services and resources, quality of library services and comfort of the working environment at the SibFU AL.

The marketing research consists of three blocks: the first block is dedicated to the analysis of comfort of the library for its users; the second is dedicated to the information and bibliographical services and resources of the SibFU AL, and the third one is dedicated to the quality of the staff work and the efficiency of service provided to the readers. For each block, a questionnaire of 10-12 questions of open and closed types was made. Among the polled, there were some students, post-graduates, teachers and employees of the Siberian Federal University, as they are the main and the most active users of the Academic Library. During the research 250 respondents selected by simple random sampling were interviewed. The research was carried out in May, 2012.

\section{Material and Methods}

\subsection{Comfortable Working Environment at the SibFU AL}

The working environment makes a considerable impact on the working capacity and general psychological state of a person, so for every organization it is important to create comfortable conditions not only for work, but also for relaxation of the people. It is especially topical for the organizations that deal with providing information services to the wide sections of population.

Readers' survey on the present block was carried out in the reading rooms of the SibFU AL. The choice of place was conditioned by the fact that the library visitors spend more time in the reading rooms, and it is right to evaluate their satisfaction there.

The first question of the survey was dedicated to the most preferable time for reading among students. The research showed, that $60 \%$ of the respondents visit the library in their free time, while $20 \%$ do it during the exam session and $28 \%$ in the period between the sessions.

The next question concerned the library schedule: $55 \%$ of the surveyed are satisfied with it, $30 \%$ consider it inconvenient and $15 \%$ cannot adjust themselves to it. It is worth mentioning that a considerable part of the respondents is not satisfied with the working time of the library, so it should be changed to make it more comfortable for the visitors. The majority of the respondents also remarked that on Sundays the library should work less, but during the exam session its working time should be extended.

In the result of the survey we managed to find out that the majority of the readers $(87 \%)$ prefer the SibFU AL to the others, and only $13 \%$ choose other libraries. It proves that the library is in demand and favour among the readers.

The majority of the respondents $(68 \%)$ also said that usually they find the required literature at the library. Though indirectly, this data reflects the satisfaction with the library 
funds, and proves the timely acquisition of new printed and electronic publications.

The received data shows, that most frequently the users use the library to use the Internet (55\%), a small number of visitors come to find a certain document $(20 \%)$ and to see some general literature on this or that topic $(18 \%)$. An insignificant number of readers come here in search for some rare books $(7 \%)$. It is worth mentioning that the peculiarity of the modern library service is the domination of its informative function over the others: very often the readers come for the information they search for in the Internet, and analysing that they make decision on the need of some documents or books $[1,106 \mathrm{p}$.$] .$

To the question "What attracts you at the SibFU AL?" 38\% of the polled replied: good reference tools, $25 \%$ appreciate the special library funds (thesis and thesis summaries, patents etc.), $16 \%$ like the large choice of Russian and foreign publications, $11 \%$ spoke of the universality of the funds and only $10 \%$ of readers come here for some rare books (see Fig. 1). Moreover, many respondents also mentioned the convenient working time, comfortable conditions, attentive attitude of the staff to the readers, wide variety of books and the modern reading rooms equipped with computers and multimedia equipment.

The majority of the respondents are prevented from efficient work in the SibFU library by the necessary books being taken by other readers (36\%), the incomplete reflection of the funds in the electronic catalogue $(18 \%)$, absence of the necessary books in the reading rooms, slow service $(16 \%)$. Some users find it difficult to operate the catalogues and funds of the library (12\%). Several polled people feel frustrated because of the absence of some certain Russian (9\%) and foreign (9\%) books in the library (see Figure 2).

In the process of the research the respondents were suggested to put in order the most advantageous conditions for work in the library according to their significance (the most important is number 1 , the next important is 2 etc.); the polled find the convenient location of the library the most important factor; the next one listed is the comfortable working environment. The convenient schedule and good attitude of the employees are almost equal in their importance. The least significant factor for the users is the availability of information on the library work and services.

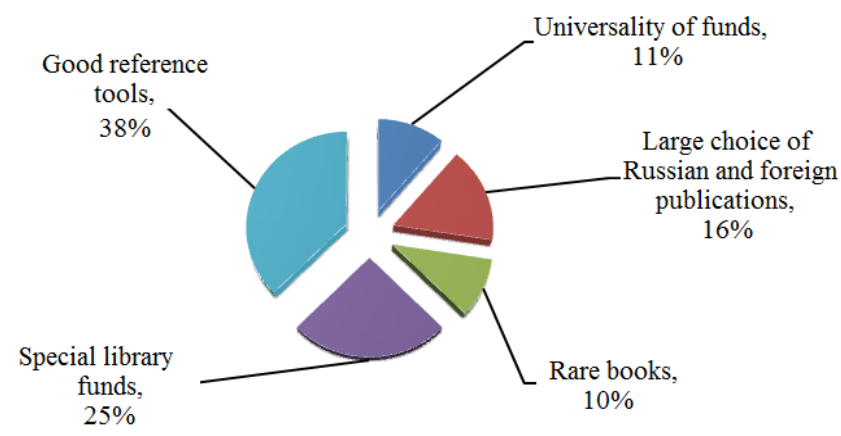

Figure 1. Replies to the question "What attracts you in the SibFU AL?"

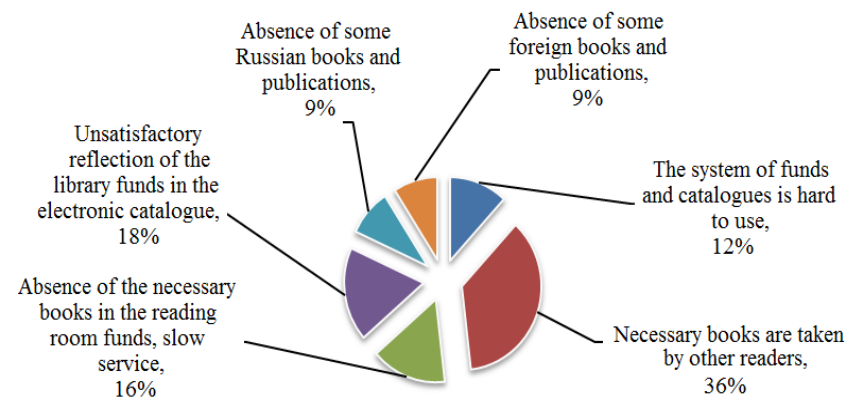

Figure 2. Replies to the question "What prevents you from efficient work in the SibFU library?"

Answering the question, "What changes would you like to see in the SibFU AL in the future?" $65 \%$ of the respondents said that the library needs a stationery kiosk and 35\% said that they needed a food kiosk.

To the question "How do you think the library can improve its work?" the majority of the readers answered that they are satisfied with everything. Though, some of them remarked that the library should acquire more books and open new branches, extend its working hours. Answering the "Your remarks and offers?" question, many people also suggested to shorten working hours on Sundays and extend working hours during the exam session.

As a conclusion we can summarize, that despite of some shortcomings, the users of the SibFU AL are satisfied with the regime and conditions of the library's work.

\subsection{Information Resources and Services Provided by the SibFU AL}

The most important function of the today's libraries is provision of free and unlimited access to resources and services to their users. The block of the marketing research analysing the users' demand for information and library resources and services of the SibFU AL was made separately for printed and electronic publications. Among the electronic sources, the considered sources were the ones generated by the library (the electronic catalogue, specific electronic collections, teaching materials), the acquired ones (Russian and foreign data bases) and the common access resources of the Internet (the virtual reading room).

The research on this block was carried out in the reading rooms, as it is the place where the most active users aware of the information sources and services are found, and it is where the majority of readers use the electronic catalogue, Russian and foreign data bases, virtual reading rooms, virtual reference service and other services provided by the library.

The main part of respondents of this survey block consisted of university students $(90 \%)$, the rest were university employees $(10 \%)$. This can be explained by the fact that the marketing research was carried out during the summer session, and during this period the major part of the users is students.

To the question, "For what purposes do you use the information resources of the library?" the majority of the 
respondents $(77 \%)$ said that they use them for their educational activities, $20 \%$ said that they use them for relaxation and only $10 \%$ - for professional activity. This result can be explained by the profile of the library (university library), the main activity trend of which is the educational activity.

The answers to the question "Do you always find the information you need in the library? are distributed in the following way: always $-25 \%$, usually, but not always $-63 \%$, and no $-12 \%$. From the answers we can see, that not all the users succeed to find the information they need. In the future it can lead to the loss of some library users. This problem can be solved only with the more careful attitude of the library employees to the readers, by their strive to help the readers find the literature and also by providing individual consultations. Following these principles, the library can both retain the present readers and attract some new ones.

The question "What types of information resources do you find the most interesting?" showed that the most demanded sources are the Internet sources $(50 \%)$, then comes the electronic catalogue and electronic library (35\%), printed publications $(27 \%)$ and the least interesting for the readers is multimedia collection (5\%).

The next question was devoted to the library funds. The research showed that the most demanded fund is the educational $(55 \%)$ one; scientific fund is less demanded $(37 \%)$. The least demanded funds, according to the poll, were fiction and periodical publication funds (10\%). And again, these answers can be explained by the specificity of the library. To the question "Are you satisfied with the access to the funds?" $80 \%$ of the respondents gave the positive answer. It proves their general satisfaction; however, it is not enough to speak of the quality and the completeness of the funds that is why the respondents had to answer an additional question. Figure 3 presents the proportion of the fund completeness evaluation according to the polled.

As an addition, the respondents were suggested to evaluate the quality of the information services provided at the SibFU AL. Among the studied characteristics, there were: quality of the fund completeness, working environment, technical equipment, information search and library service quality (see Figure 4). The quality of the fund completeness was assessed by $48 \%$ of respondents as "good"; the conditions created for the readers were assessed as "excellent" by $56 \%$ of the respondents; the equipment was assessed as "excellent" by $64 \%$ of the respondents, the quality of information search in the electronic catalogue was evaluated as "good" and "excellent" by $40 \%$ of the respondents, and only $12 \%$ of the respondents said that the service quality is "excellent"

To the question "What information resources of the SibFU AL do you need for your work?" the answers were distributed in the following way: books $-55 \%$, thesis and thesis summaries $-43 \%$, electronic collections and works by the university teachers $-27 \%$, teaching materials $-25 \%$ and periodicals $-22 \%$.

The question "Are you satisfied by the resourced provided by the library?" revealed the following opinions of the library users: books $-3,1$ score $^{1}$, periodicals $-2,8$ score, thesis and thesis summaries $-2,96$ score, teaching materials - 3,2 score, electronic collections - 3,1 score, works by the university teachers $-3,25$ score. According to the results, library users are generally satisfied with the information resources provided by the library.

After that, the respondents were asked a question on the main sources of getting the information about the library resources. More than a half of the readers do it on their own $(60 \%), 25 \%$ find it on the library web-site, $17 \%$ of the polled ask the library staff for consultation, $20 \%$ get the information from their friends, group mates and colleagues, and 30\% of the respondents get the information from their teachers.

The next two questions were devoted to the electronic resources acquired by the library. "What foreign data bases do you use most frequently?" Web of Science is preferred by $18 \%$, EBSCO Publishing by $5 \%$, and only $5 \%$ of the respondents use such data bases as Oxford Journals, Cambridge University Press, The Economist magazine (see Figure 5). These answers lead us to the following conclusion: the major part of the foreign electronic resources acquired by the SibFUAL, remains non-demanded. However, it does not mean that the library has to cancel the subscriptions to these information sources; we state that the modern reader is not ready to receive this unique high-quality information which the library is able to provide right now. Among the main reasons that would explain such results, we can list the following: not knowing the foreign language; the general discouraging atmosphere typical for the whole modern education system; the students' not wishing to get new knowledge themselves, not caring about their self-education and self-improvement.

As for the Russian data bases, the readers use the information from the Academic Electronic Library (eLIBRARY.RU) (33\%), Integrum (20\%), Electronic Data Base of the Russian State Library (13\%) and Electronic Data Base "BOOK.RU" (13\%), and such data bases as Russian Information System, Electronic Data Base of Grebennikov Publishing House. 12\% of the polled do not use any Russian data bases at all and explain it in the following way: "I don't know how to use them... There is no need in using them... I can find everything I need in Google". The results are presented in Figure 6. As we can see from the answers, the situation concerning the Russian data bases is different from that of the foreign ones: the library users show more interest to them.

Among the ways to improve the work with information resources and services, the users list: "Organizing practical seminars on using integrated library and information systems, timely informing the users on new resources and services, providing more help of the library staff to assist the users in finding the necessary resources and services, providing access to the electronic resources from home computers, getting information on electronic libraries in electronic

${ }^{1}$ Averageratingof the users' attitude accordingtoLikertscale. 
form".

One of the most important questions for evaluation of the library information resources is: "What would you like to improve in the work with information resources at the SibFU AL?" The replies were distributed in the following way: $8 \%$ of the polled said that they see no need in such improvement; the same number of the respondents wished the library acquired more printed and electronic publications. Several respondents asked to "increase the number of books", "improve the requirement systems and their performance", "hire friendly staff", and "improve the electronic data base".
The rest of the readers gave no answer to the question.

From the listed services of the SibFU AL, the majority of the polled remarked that they use the electronic catalogue $(52 \%)$, the electronic library (52\%), the virtual reading room $(40 \%)$ and the electronic reference system (16\%). It can be explained by the fact that these resources enable the users to find the necessary information on any topic in a fast and efficient way. From the poll, we also found that the majority of the users get the information about the library services on the library web-site $(50 \%)$ and the university web-site $(50 \%)$.

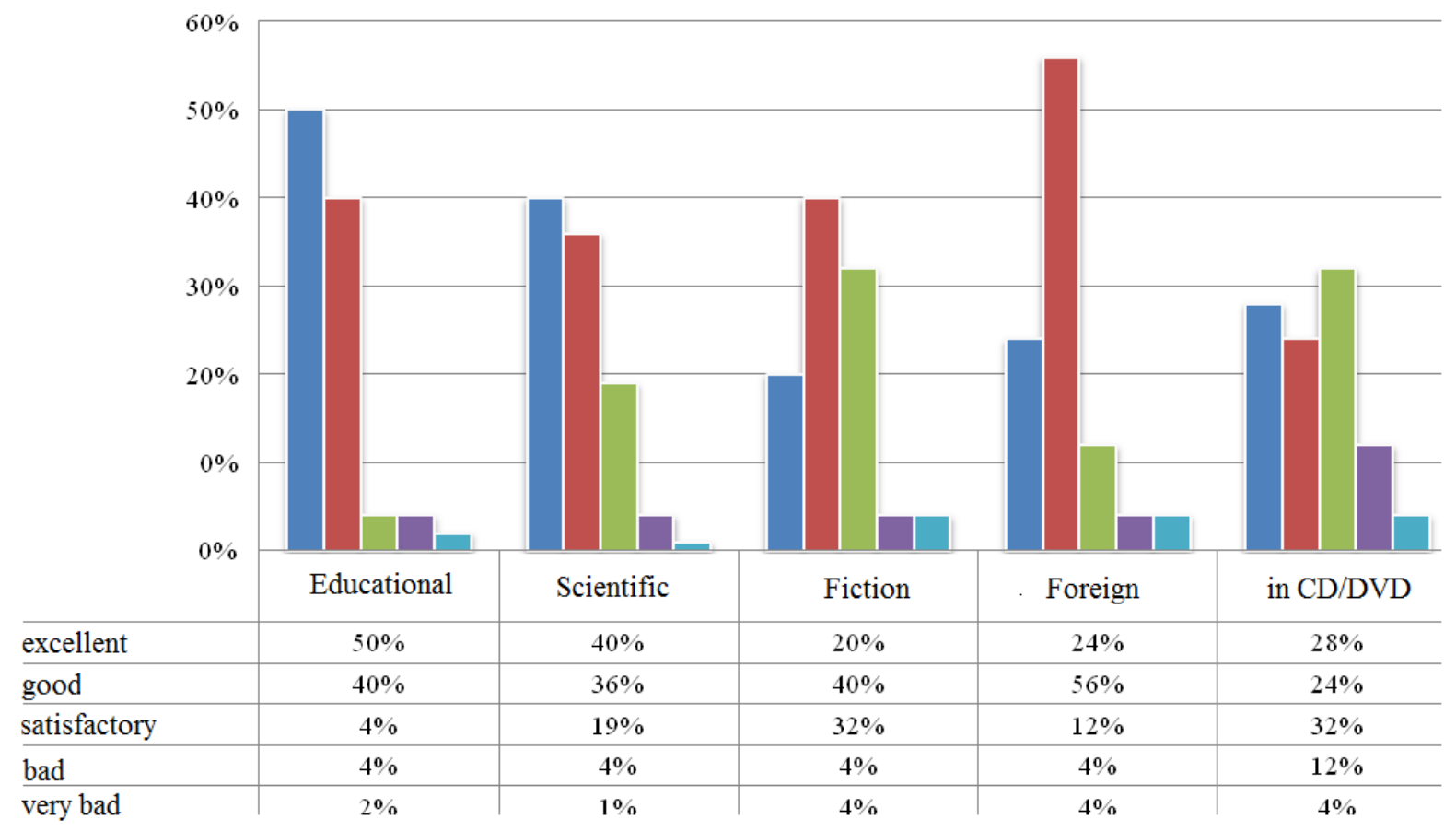

Figure 3. Library funds completeness evaluation

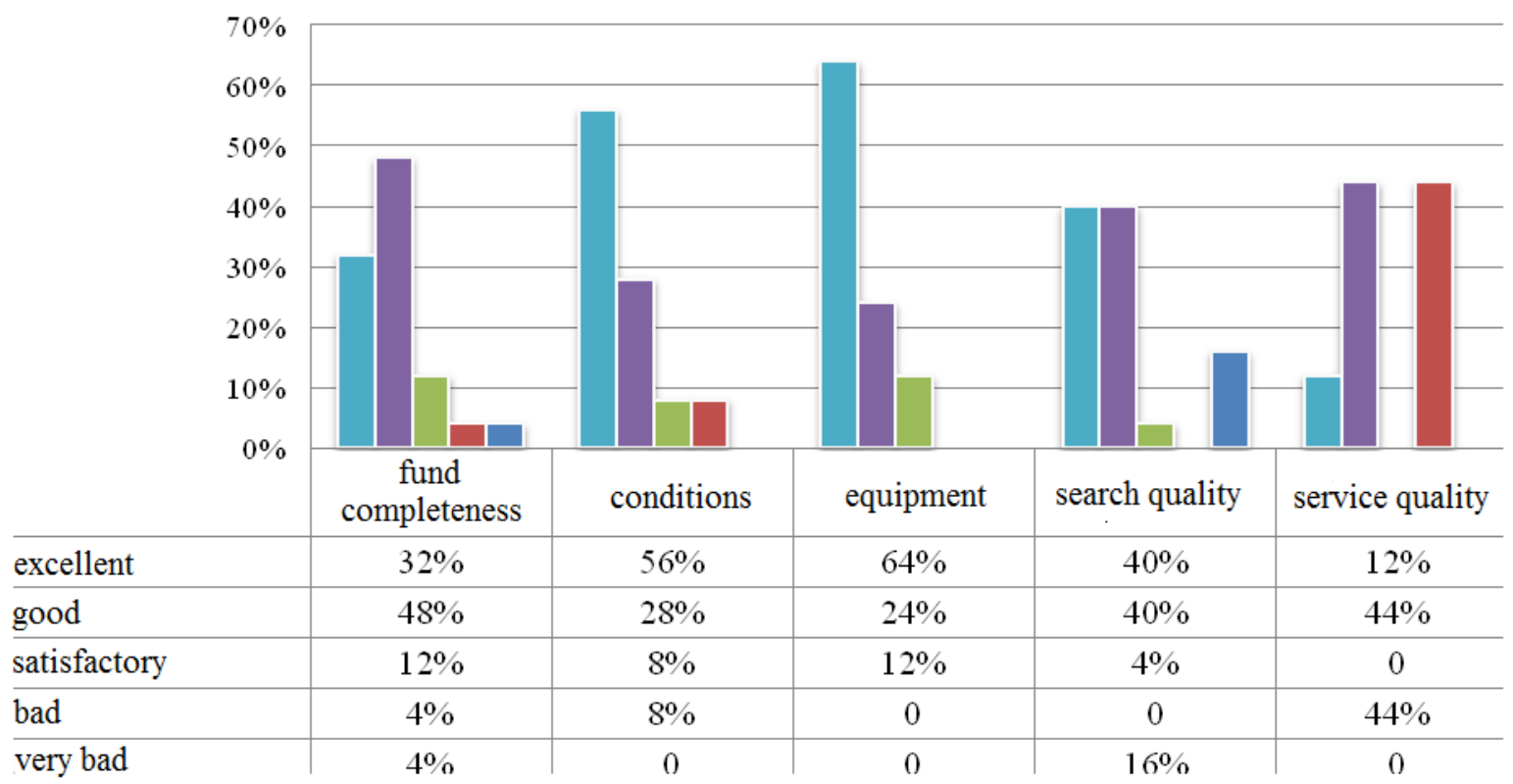

Figure 4. Service quality assessment 
The readers came up with the following suggestions and remarks for improvement of the information and library service: "improve the electronic catalogue search option, install more sockets for laptops, provide the access to the USB ports at electronic reading rooms, open the access for watching video materials at the reading rooms, extend the working hours of the library for at least half an hour, put some sofas at the reading rooms".

\section{EBSCO Publishing $\square$ Springer and Kluwer Elsevier Other}

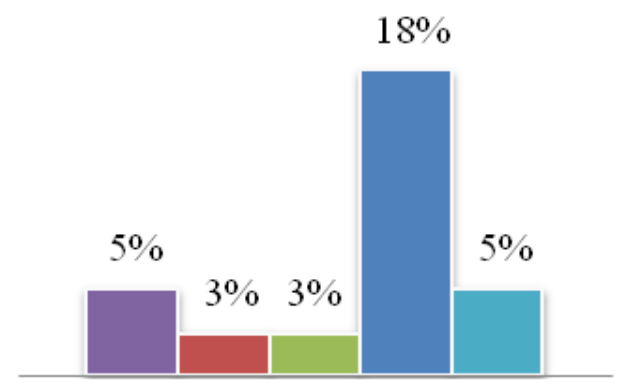

Figure 5. Foreign data bases

$\begin{array}{ll}\text { eLIBRARY.RU } & \text { Integrum } \\ \text { EastView } & \square \text { Electronic Data Base } \\ \text { "BOOK.RU" } & \text { of Russian State Library } \\ \text { Electronic Data Base } & \end{array}$

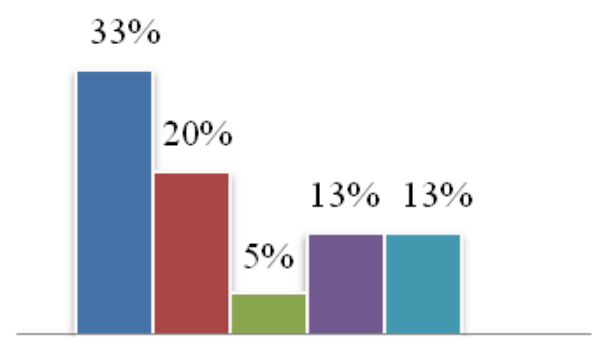

Figure 6. Russian data bases

\subsection{Quality of the Library Service}

The service quality is evaluated by the readers as they assess the completeness and availability of information, quality of the staff and the service provided, the conditions of library use $[2,54$ p.]. With the quality category it is also possible to evaluate the satisfaction of the readers by the service quality. The service quality is also influenced by such personal features of the librarian as competence, communicability, friendliness and politeness [1].

For making a survey on this block of research, two departments of the Academic Library were selected: the department of social, economic, humanitarian and natural science literature (room 1-14) and the department of architecture, construction and technical science (room 1-28).

Answering the questions "How do you evaluate the literature provided by the SibFU AL? Does it meet your requirements?" $71 \%$ of the respondents said that the literature meets their requirements, and only $2 \%$ said it was partially matching. It proves that the acquirement sector of the library works efficiently and that the staff of the library departments succeeds to find the right literature for the customers.

The next question concerned the work of the library staff. $54 \%$ of the polled evaluate it as good, $33 \%$ say that it is excellent and $13 \%$ say it is acceptable. It means that the library staff has been working fine, the employees have high qualification and succeed to carry out their responsibilities at the working place.

From the answers to the question concerning the quality of the staff work we can see that the majority of the respondents assess it as "excellent" (64\%) and "good" (36\%). The users leave positive references about the librarians and their work. It means that the users need their help and really appreciate it.

In the process of the research the satisfaction of the users with the quality of resources and service at the SibFU library was revealed: many respondents consider the quality of the services and recourses to be high $90 \%$ and only $10 \%$ say they are not satisfied.

The service efficiency at the library was highly evaluated by the visitors: $40 \%$ of the respondents say that the service is fast, $27 \%$ say it is very fast and $33 \%$ find it satisfactory. The main reason of high service efficiency is using the electronic means of reader service.

To the question "How do you evaluate the communicative features of the librarians?" around $50 \%$ of the respondents said that they highly evaluate the professional and communicative features of the library workers.

The last question of the survey is closely connected to the communicative features evaluation, but its target was to complete and extend the previous answers from the point of view of general understanding. Many respondents (54\%) remarked that the library workers are always attentive, supportive and friendly to the readers. The main reasons are good professional and communicative features of the librarians, their ability to carry out efficient two-way contact, and the right choice of personnel for serving the readers.

Let us illustrate the results with the following diagrams (see Figures 7-8).

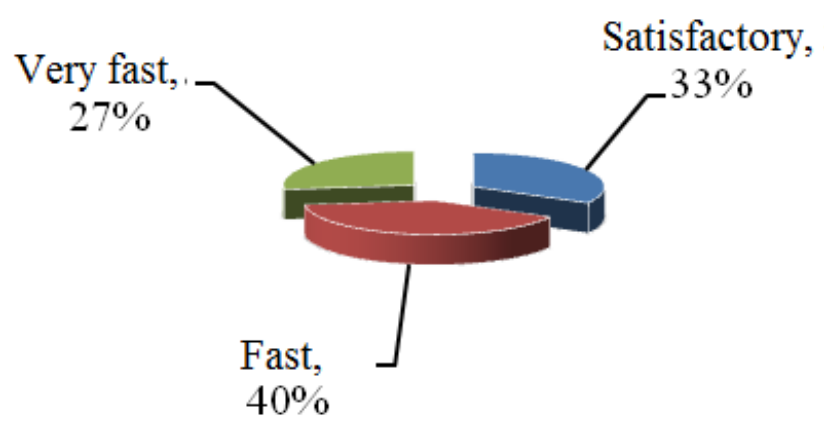

Figure 7. Service efficiency evaluation 


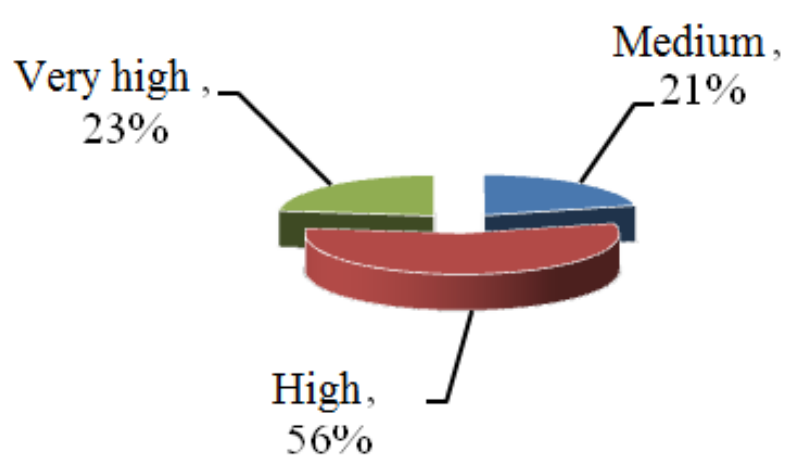

Figure 8. Attention, helpfulness and friendliness of the librarians

The block analysed the level of general readers' satisfaction, which determines the efficiency of the library work as a whole. According to the analysis of the questionnaire answers we can conclude that the majority of the polled are satisfied with the services and resources provided by the SibFU AL. However, a small part of the polled remarked that they are not always satisfied with the service efficiency and the attitude of the library staff.

\section{Conclusion}

In the process of the marketing research, the analysis of comfort of the working environment, demand for the information and library service and resources of the library, and the quality of library service at the SibFU AL has been carried out.

The research of the information and library resources and services of the Academic Library confirmed the existing contradiction between the resources and services provided by the library and demand for them among the readers. The survey results show that the majority of the resources and services remain non-demanded: the respondents admit the potential importance of the offered resources and services, but are "in no hurry" to use them.

However, the majority of the users have the positive image of the AL; they are not indifferent to the library problems, for the respondents it plays an important role both as a source of information and a social centre. Even speaking of shortcomings in the library's work, the respondents express some warm feelings for the library and mention the friendliness and the high professional features of the librarians

\section{REFERENCES}

[1] Basamygina I.N, Apanasenko A.A. Marketing kak tekhnologiia upravleniia sovremennoy bibliotekoy [Marketing as a technology of a modern library management] Moscow, 2009, 128 P. Б

[2] Vasilyev I.G., Ille M.E., Ravinskiy D.K. Sotsiologicheskie issledovaniia $v$ bibliotekakh [Sociological researches at libraries] Saint Petersburg, 2002, 176 P.

[3] Suslova I.M. Practicheskiy marketing v bibliotekakh[Practical marketing at a library] Moscow, 2004, $144 \mathrm{P}$.

[4] Kliuev V.K., Iastrebova E.M. Marketingovaia orientatsiia bibliotechno-informatsionnoy deatel'nosti (Marketing $v$ sisteme upravleniia bibliotekoy) [Marketing orientation of library information activities (Marketing in the library management system)] Moscow, Ministry of Culture of the Russian Federation, Moscow State University of Culture and Arts; Moscow, 2001. 144 P. 